\title{
Image Enhancement Techniques in Digital Image Processing
}

\author{
K. Shanmugapriya, D. Jeya Priya, N. Priya
}

\begin{abstract}
The procedure of image enhancement was to adjusting two or more pictures of the same scene. This procedure worried with assigning one picture as the reference also applying geometric change to alternate pictures so they adjust to suggestion. Ordinarily, the pictures are caught under variable conditions that can change camera setting. Misalignment can likewise be the consequence of lens also sensor or differentiate between catch gadgets. A geometric change maps areas in one picture to late areas in another. The progression of conclusive the ideal geometric change parameters key to the picture enhancement process. Picture enhancement was intermittently appropriate as a preparatory stride as a part of other picture hassling applications. For instance, you can utilize picture enhancement to adjust satellite pictures or to grouping of restorative pictures caught with diverse symptomatic modalities like MRI also SPECT. Picture enrollment permits you to examination of diverse picture estimations.
\end{abstract}

Keywords : wavelets, compression, modality, degradation

\section{INTRODUCTION}

The picture adapting strategies to clarifies with control of advanced pictures through a computerized PC. It was a sublet frameworks yet establish absolutely of pictures. Plunge concentration of adding a PC framework that performs hassling on a picture[1],[3],[5]. The information of a picture of framework hassles the picture hassle proficient calculations, to produce picture. Picture adapting fundamentally incorporates the accompanying three stages: (an) Importing the picture by means of picture obtaining instruments (b) Analyze also controlling the picture also (c) Output in which result can be modified picture or report that depends on picture examination [2 ],[ 4],[6]

There are two sorts of strategies appropriate for picture adapting to be specific, simple also computerized picture hassling. Simple picture adapting that appropriate of that printed copies like that picture printouts also image duplicates. Image experts that different essentials under tagging while appropriate that vassal system. Computerized image adapting strategies helped that control of that advanced images by appropriate PCs. The three general stages appropriate computerized method of pre-adapting, improvement, also show, data extraction.

(a) Picture Procurement: Picture obtaining that picture handling that comprehensively describe as recovering that

Revised Manuscript Received on July 22, 2019.

K.Shanmugapriya , Department of CSE, Bharath Institute of Higher EducationandResearch,Chennai,IndiaEmail:shanmugapriyabiher@gmail.com

Ms.D.Jeya Priya, Department of CSE, Bharath Institute of Higher EducationandResearch,Chennai,India Email:priyajp8@gmail.com

Ms.N.Priya, Department of CSE, Bharath Institute of Higher EducationandResearch,Chennai,India Email: priyabiher@gmail.com picture from source, as rule equipment based source, which can be gone through that procedures want to develop a short time delay[7],[ 9],[11]. Affecting picture securing was the initial phase in the work process succession in light of the fact these, without a image handling was un-realistic. That picture that was gained was totally grungy also was the consequence that equipment was appropriate to produce it, which can be essential that few fields a reliable benchmark from that work. One of the great objectives was procedure that has a wellspring of information these works inside such controlled also measured rules of a same picture.

(b) Image preprocessing: Image pre-adapting can to a great degree build the exactness of that optical review. Some channel operations that guaranteed image points of interest empower that simpler are speedier assessment. Clients can upgrade a camera picture with only a couple clicks[8],[10] ,[12]

(c) Image Upgrade: The unmistakable goal of picture improvement was to prepare a given image that the outcome was more suitable the first picture of a separate application. The image highlights like edges, limits, and to make a realistic show most supportive for presentation also investigation[13], [15],[ 17]

(d) Image Rebuilding: That motivation picture reclamation was to "make up for" "fix" imperfections that debase a picture. Decrease comes that numerous structures, the example, sequence obscure also commotion[38],[40],. The movement obscure, it was conceivable to concoct gauge of the real obscuring work also "fix" the obscure to restore that first picture. The situations of a image was ruined by commotion, that best we might want to do was to reward for the debasement it brought on. It was venture, we present also execute a few of the strategies appropriate a part of the picture adapting world to restore picture[14],[ 16], [18]

(e) Color picture handling: The human framework can dissect a huge number of shading shades also intensities; it was around 100 shades of image darkness. It was manner, in that picture, of more data contained in that shading, also it was additional data can be appropriate to improve image investigation, e.g. image proof also extraction taking into account shading. There are outright amounts are appropriate to depict a particular shading. The tone was supreme on that predominant wavelength.

(f) Wavelets additionally Multi-assurance Processing: Wavelets are the foundation for describing pictures in various degrees of assurance[19],[21],[23]. Pictures subdivision continuously into more diminutive regions for 
data weight likewise for pyramidal portrayal

(g) Compression: Compression oversees methodologies for the accumulating required to store an image or the information exchange ability to transmit it. Especially in the businesses of web it was all that much critical to pack data.

(h)Morphological Processing: Its instruments for construe picture parts that was useful in the portrayal likewise delineation of shape.

(I) Segmentation: Segmentation methods bundle an image into its constituent parts or dissents. When in doubt, independent division was among the most troublesome mistake in cutting edge picture taking care of. An extreme division was the method far toward powerful course of action of imaging things to be perceived freely.

(j) Representation additionally Description: removing likewise depiction frequently take after the yield of a division arrange, which generally was rough pixel data, establishing either the farthest point of an area every one of the focuses in the area itself. Picking a characterizing was just piece of the answer for changing crude information into a structure suitable for resulting PC adapting[32],[34],[36]. Removing characteristics that some of quantitative data that interest are essential for separating individual class items from another class

(k) Object acknowledgment: Recognition implies that appoints a mark, for example, "vehicle" to an item in view of its descriptors[37],[39],[41]

(1) Knowledge Base: Knowledge might be as fundamental as listing territories of an image where the information of premium was known not found, in that was way compelling the interest that must be coordinated in searching for that information. The learning base also can be extremely astounding, for instance, an important summary of all noteworthy possible flaws in a materials examination an image database containing high-assurance satellite photos of a territory in regards to change-rise applications

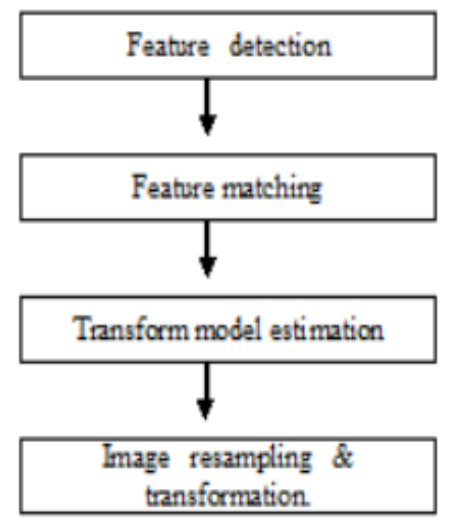

I. Highlight acknowledgment: In that frameworks, striking also articles like corners, close utmost territories, edges, shapes, line crossing point are essentially or in a perfect world unequivocally[31],[33],[35]. These components are used to further taking care of. Those segments point delegates that centre of gravity in that specific center it's also called control centers. To find highlight sets of information also picture have enough essential parts.

II. Highlight planning: In that case, correspondence segments recognized that identified picture also perceived in that referenced picture was set up. The particular segment descriptors also comparability measures close by spatial associations among the components are used hence. The segment change routines should adequately to be to that perceived components.

III. Change estimation: In this sort also parameters of the claimed mapping limits, sequencing the picture also impute picture are assessed

Higence Engineering \& Sciences Publication 
[25],[27],[29]. The parameters of mapping enrolled limited by technique for the highlight. This kind of mapping framework picked by a data about the getting handle also expected picture defilement. If no previous information was available then the model should versatile also typical degradation was appear.

IV. Picture reconsidering also change: This photo was changed the strategy for that mapping limits[26],[28],[30]. Picture data in non entire number headings were enrolled the fitting presentation model. The choice of taking after procedure depends on that trade of between the asked for precision of the multifaceted nature.

\section{CONCLUSION}

The purpose of a photo selection was to find looking at down to earth zones in two or more pictures. It was used as a piece of various fields like PC vision, therapeutic imaging, also remote recognizing. It was required for joining information taken from sensors choosing changes in pictures taken at assorted time (multi common selection), gathering three dimensional information from pictures where camera or the things in the scene was moving (multi view selection) or scene to model enlistment.

\section{REFERENCES}

[1] Kumaravel A., Rangarajan K.,Algorithm for automaton specification for exploring dynamic labyrinths,Indian Journal of Science and Technology,V-6,I-SUPPL5,PP-4554-4559,Y-2013

[2] P. Kavitha, S. Prabakaran "A Novel Hybrid Segmentation Method with Particle Swarm Optimization and Fuzzy C-Mean Based On Partitioning the Image for Detecting Lung Cancer" International Journal of Engineering and Advanced Technology (IJEAT) ISSN: 2249-8958, Volume-8 Issue-5, June 2019

[3] Kumaravel A., Meetei O.N.,An application of non-uniform cellular automata for efficient cryptography,2013 IEEE Conference on Information and Communication Technologies, ICT 2013,V-,I-,PP-1200-1205,Y-2013

[4] Kumarave A., Rangarajan K.,Routing alogrithm over semi-regular tessellations,2013 IEEE Conference on Information and Communication Technologies, ICT 2013,V-,I-,PP-1180-1184,Y-2013

[5] P. Kavitha, S. Prabakaran "Designing a Feature Vector for Statistical Texture Analysis of Brain Tumor" International Journal of Engineering and Advanced Technology (IJEAT) ISSN: 2249-8958, Volume-8 Issue-5, June 2019

[6] Dutta P., Kumaravel A.,A novel approach to trust based identification of leaders in social networks,Indian Journal of Science and Technology,V-9,I-10,PP--,Y-2016

[7] Kumaravel A., Dutta P.,Application of Pca for context selection for collaborative filtering,Middle - East Journal of Scientific Research,V-20,I-1,PP-88-93,Y-2014

[8] Kumaravel A., Rangarajan K.,Constructing an automaton for exploring dynamic labyrinths,2012 International Conference on Radar, Communication and Computing, ICRCC 2012,V-,I-,PP-161-165,Y-2012

[9] P. Kavitha, S. Prabakaran "Adaptive Bilateral Filter for Multi-Resolution in Brain Tumor Recognition" International Journal of Innovative Technology and Exploring Engineering (IJITEE) ISSN: 2278-3075, Volume-8 Issue-8 June, 2019

[10] Kumaravel A.,Comparison of two multi-classification approaches for detecting network attacks, World Applied Sciences Journal,V-27,I-11,PP-1461-1465,Y-2013

[11] Tariq J., Kumaravel A.,Construction of cellular automata over hexagonal and triangular tessellations for path planning of multi-robots,2016 IEEE International Conference on Computational Intelligence and Computing Research, ICCIC 2016,V-,I-,PP--,Y-2017
[12] Sudha M., Kumaravel A.,Analysis and measurement of wave guides using poisson method,Indonesian Journal of Electrical Engineering and Computer Science,V-8,I-2,PP-546-548,Y-2017

[13] Ayyappan G., Nalini C., Kumaravel A.,Various approaches of knowledge transfer in academic social network,International Journal of Engineering and Technology,V-,I-,PP-2791-2794,Y-2017

[14] Kaliyamurthie, K.P., Sivaraman, K., Ramesh, S. Imposing patient data privacy in wireless medical sensor networks through homomorphic cryptosystems 2016, Journal of Chemical and Pharmaceutical Sciences92.

[15] Kaliyamurthie, K.P., Balasubramanian, P.C. An approach to multi secure to historical malformed documents using integer ripple transfiguration 2016 Journal of Chemical and Pharmaceutical Sciences92.

[16] A.Sangeetha,C.Nalini,"Semantic Ranking based on keywords extractions in the web", International Journal of Engineering \& Technology, 7 (2.6) (2018) 290-292

[17] S.V.GayathiriDevi,C.Nalini,N.Kumar,"An efficient software verification using multi-layered software verification tool "International Journal of Engineering \& Technology, 7(2.21)2018 454-457

[18] C.Nalini,ShwtambariKharabe,"A Comparative Study On Different Techniques Used For Finger - Vein Authentication", International Journal Of Pure And Applied Mathematics, Volume 116 No. 8 2017, 327-333, Issn: 1314-3395

[19] M.S. Vivekanandan and Dr. C. Rajabhushanam, "Enabling Privacy Protection and Content Assurance in Geo-Social Networks", International Journal of Innovative Research in Management, Engineering and Technology, Vol 3, Issue 4, pp. 49-55, April 2018.

[20] Dr. C. Rajabhushanam, V. Karthik, and G. Vivek, "Elasticity in Cloud Computing", International Journal of Innovative Research in Management, Engineering and Technology, Vol 3, Issue 4, pp. 104-111, April 2018.

[21] K. Rangaswamy and Dr. C. Rajabhushanamc, "CCN-Based Congestion Control Mechanism In Dynamic Networks", International Journal of Innovative Research in Management, Engineering and Technology, Vol 3, Issue 4, pp. 117-119, April 2018.

[22] Kavitha, R., Nedunchelian, R., "Domain-specific Search engine optimization using healthcare ontology and a neural network backpropagation approach”, 2017, Research Journal of Biotechnology, Special Issue 2:157-166

[23] Kavitha, G., Kavitha, R., "An analysis to improve throughput of high-power hubs in mobile ad hoc network", 2016, Journal of Chemical and Pharmaceutical Sciences, Vol-9, Issue-2: 361-363

[24] Kavitha, G., Kavitha, R., "Dipping interference to supplement throughput in MANET" , 2016, Journal of Chemical and Pharmaceutical Sciences, Vol-9, Issue-2: 357-360

[25] Michael, G., Chandrasekar, A.,"Leader election based malicious detection and response system in MANET using mechanism design approach", Journal of Chemical and Pharmaceutical Sciences(JCPS) Volume 9 Issue 2, April - June 2016

[26] Michael, G., Chandrasekar, A.,"'Modeling of detection of camouflaging worm using epidemic dynamic model and power spectral density", Journal of Chemical and Pharmaceutical Sciences(JCPS) Volume 9 Issue 2, April - June 2016

[27] Pothumani, S., Sriram, M., Sridhar, J., Arul Selvan, G., Secure mobile agents communication on intranet,Journal of Chemical and Pharmaceutical Sciences, volume 9, Issue 3, Pg No S32-S35, 2016

[28] Pothumani, S., Sriram, M., Sridhar, Various schemes for database encryption-a survey, Journal of Chemical and Pharmaceutical Sciences, volume 9, Issue 3, Pg NoS103-S106, 2016

[29] Pothumani, S., Sriram, M., Sridhar, A novel economic framework for cloud and grid computing, Journal of Chemical and Pharmaceutical Sciences, volume 9, Issue 3, Pg No S29-S31, 2016

[30] Priya, N., Sridhar, J., Sriram, M. "Ecommerce Transaction Security Challenges and Prevention Methods- New Approach" 2016 ,Journal of Chemical and Pharmaceutical Sciences, JCPS Volume 9 Issue 3.page no:S66-S68 .

[31] Priya, N.,Sridhar,J.,Sriram, M."Vehicular cloud computing security issues and solutions" Journal of Chemical and Pharmaceutical Sciences(JCPS) Volume 9 Issue 2, April - June 2016

[32] Priya, N., Sridhar, J., Sriram, M. "Mobile large data storage security in cloud computing environment-a new approach" JCPS Volume 9 Issue 2. April - June 2016

[33] Anuradha.C, Khanna.V, "Improving network performance 
and security in WSN using decentralized hypothesis testing "Journal of Chemical and Pharmaceutical Sciences(JCPS) Volume 9 Issue 2, April June 2016 .

[34] Anuradha.C, Khanna.V, "A novel gsm based control for e-devices" Journal of Chemical and Pharmaceutical Sciences(JCPS) Volume 9 Issue 2, April - June 2016 .

[35] Anuradha.C, Khanna.V, "Secured privacy preserving sharing and data integration in mobile web environments " Journal of Chemical and Pharmaceutical Sciences(JCPS) Volume 9 Issue 2, April - June 2016.

[36] Sundarraj, B., Kaliyamurthie, K.P. Social network analysis for decisive the ultimate classification from the ensemble to boost accuracy rates 2016 International Journal of Pharmacy and Technology

[37] Sundarraj, B., Kaliyamurthie, K.P. A content-based spam filtering approach victimisation artificial neural networks 2016 International Journal of Pharmacy and Technology83.

[38] Sundarraj, B., Kaliyamurthie, K.P. Remote sensing imaging for satellite image segmentation 2016 International Journal of Pharmacy and Technology8 3 .

[39] Sivaraman, K., Senthil, M. Intuitive driver proxy control using artificial intelligence 2016 International Journal of Pharmacy and Technology84.

[40] Sivaraman, K., Kaliyamurthie, K.P. Cloud computing in mobile technology 2016 Journal of Chemical and Pharmaceutical Sciences92.

[41] Sivaraman, K., Khanna, V. Implementation of an extension for browser to detect vulnerable elements on web pages and avoid click jacking 2016 Journal of Chemical and Pharmaceutical Sciences92.

\section{AUTHORS PROFILE}

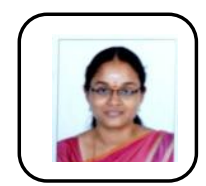

K. Shanmugapriya Assistant Professor, Department of Computer Science \& Engineering, Bharath Institute of Higher Education and Research, Chennai, India

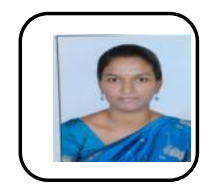

Ms. D. Jeya Priya Assistant Professor, Department of Computer Science \& Engineering, Bharath Institute of Higher Education and Research, Chennai, India

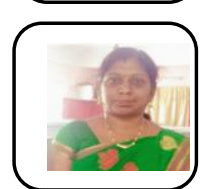

Ms. N. Priya Assistant Professor, Department of Computer Science \& Engineering, Bharath Institute of Higher Education and Research, Chennai, India 